\title{
Response of Faba bean (Vicia faba) to Application of Phosphorus Fertilizer Levels at Lemu Bilbilo District, South-eastern Ethiopia
}

\author{
Mengistu Chemeda*, Anbessie Debebe, Gobena Negasa \\ Ethiopian Institute of Agricultural Research, Kulumsa Agricultural Research Center (EIAR/KARC), \\ P.O.Box 489, Asella, Ethiopia
}

\begin{abstract}
For two consecutive years (2017 - 2018), field experiments were carried out on different farm lands and provinces at Lemu-Bilbilo highland, southeastern Ethiopia, to assess, evaluate, and give recommendations of Phosphorus fertilizer requirement for faba bean crop by varying levels of phosphorus $(0,23,46,69,92,115 \mathrm{~kg}$ $\mathrm{ha}^{-1} \mathrm{P}_{2} \mathrm{O}_{5}$, and $46 \mathrm{~kg} \mathrm{ha}^{-1} \mathrm{P}_{2} \mathrm{O}_{5}+40 \mathrm{~kg} \mathrm{ha}^{-1} \mathrm{~K}_{2} \mathrm{O}$ ) on growth performance and yield. The results revealed that phosphorus levels significantly affected number of tiller per plant, plant height, number of pods per plant, harvest index, grain yield and above ground biomass yield. The higher and lower number of tiller per plant (1.43 and 0.96) were recorded from plots received 69 and $0 \mathrm{~kg} \mathrm{P}_{2} \mathrm{O}_{5}$ ha $^{-1}$ respectively. The maximum and minimum plant height and number of pods per plant $(119.6 \mathrm{~cm}$ and 13.98$)$ and $(102.7 \mathrm{~cm}$ and 11.66$)$ were recorded from plots received 92 and $0 \mathrm{~kg} \mathrm{P}_{2} \mathrm{O}_{5} \mathrm{ha}^{-1}$ respectively. Similarly the highest and lowest grain yield and above ground biomass yield (4099.6 and $\left.8127.4 \mathrm{~kg} \mathrm{ha}^{-1}\right)$ and (3073.3 and $5713.8 \mathrm{~kg} \mathrm{ha}^{-1}$ ) were recorded from plots received 115 and $0 \mathrm{~kg} \mathrm{P}_{2} \mathrm{O}_{5}$ ha $^{-1}$ respectively. Generally the result indicated that application of phosphorus $\left(69 \mathrm{~kg} \mathrm{P}_{2} \mathrm{O}_{5}\right.$ ha $^{-}$ $\left.{ }^{1}\right)$ with grain yield $\left(3996.8 \mathrm{~kg} \mathrm{ha}^{-1}\right)$, is economically feasible treatment for improving productivity of faba bean crop under the conditions of the present study.
\end{abstract}

Keywords: Experiment, Phosphorus fertilizer, Faba bean, Lemu Bilbilo, South-eastern Ethiopia

DOI: $10.7176 / \mathrm{JBAH} / 11-8-02$

Publication date: April $30^{\text {th }} 2021$

\section{INTRODUCTION}

No soil can provide high yields if it is not optimal in P (Rao et al., 1999). Phosphorus is one of the essential macronutrients required by plants. As an essential plant nutrient, $\mathrm{P}$ is involved in a wide range of plant processes from permitting cell division to the development of a good root system to ensuring timely and uniform ripening of the crop. $\mathrm{P}$ is needed most by young, fast-growing tissues, and performs a number of functions related to growth, development, photosynthesis, and utilization of carbohydrates (Rao, 1996). P is a constituent of adenosine diphosphate (ADP) and adenosine triphosphate (ATP), two of the most important substances in life processes. ATP is a source of energy for physiological processes such as biological nitrogen fixation (Giller, 2001), photosynthesis, respiration, energy storage and transfer, cell division, cell enlargement, root development, flowering, seed formation, fruiting and improvement of crop quality (Sara et al., 2013). Because of the importance of P for plant growth and yield, many compound fertilizers such as NPK used to correct major deficiencies in soil $\mathrm{P}$ content as a major element.

Optimal plant growth requires $\mathrm{P}$ in the range of $0.3-0.5 \%$ of dry matter during the vegetative growth stage. Dry matter P contents in excess of $1 \%$ may be toxic for most crops. However, many tropical food legumes are more sensitive to excess $\mathrm{P}$, and toxicity may occur at much lower shoot $\mathrm{P}$ contents, for example, $0.3-0.4 \%$ in pigeon pea and $0.6-0.7 \%$ in black gram (Bell et al., 1990). The partial productive efficiency of $\mathrm{P}$ for grain or seed is higher at early growth stages than at later stages, because $\mathrm{P}$ is needed for tillering or branching. If sufficient $\mathrm{P}$ is absorbed at early growth stages, it will be redistributed to other growing organs.

Plant roots acquire $\mathrm{P}$ as phosphate, primarily in the form of $\mathrm{H}_{2} \mathrm{PO}^{-4}$, from the soil solution (Vance et al., 2003). The concentration of $\mathrm{H}_{2} \mathrm{PO}^{-4}$ in the soil solution is often low (2 to $10 \mu \mathrm{M}$ ) (Raghothama, 1999) and, consequently, the supply of $\mathrm{H}_{2} \mathrm{PO}^{-4}$ to the root surface by diffusion is slow (Fitter and Hay, 2002). Therefore, $\mathrm{P}$ is one of the most unavailable and inaccessible macronutrients in the soil (Vance et al., 2003) and frequently limits plant growth. For this reason, application of inorganic P fertilizers to infertility soils enhance crop productivity. Site-specific $\mathrm{P}$ application to lower testing regions may be a more profitable approach, although identifying lower P regions within fields is a challenge (Ferguson et al., 2006). With increasing demand of agricultural production, phosphorus is receiving more attention as a non-renewable resource (Cordell et al., 2009; Gilbert, 2009).

A unique characteristic of $\mathrm{P}$ is its low availability due to its slow diffusion and high fixation in acid and alkaline soils. As many African soils are old and highly-weathered, P fertilizers are required virtually everywhere for all crops. Legumes, in particular, tend to have a stronger requirement for $\mathrm{P}$ than cereals due to their less-branched and less fibrous root systems (Vanlauwe et al., 2010). The higher protein content of grain legume seeds also requires greater amounts of photosynthetic to be used in synthesizing large amounts of protein (Sinclair and deWit, 1975), hence P availability is important to supply ATP for the crop. The increase of whole 
plant growth and plant nitrogen concentration in response to increased soil P supply have been noted for several leguminous species including faba bean (Israel, 1993).

\section{MATERIALS AND METHODS}

\subsection{Experimental Site Description}

The study was conducted at Lemu-Bilbilo highland, south-eastern Ethiopia. Geographically, it is located between $07^{0} 35^{\prime} 300^{\prime \prime}$ to $07^{0} 27^{\prime} 530^{\prime \prime} \mathrm{N}$, and $039^{\circ} 13^{\prime} 899^{\prime \prime}$ to $039^{\circ} 15^{\prime} 133^{\prime \prime}$ E with an elevation ranging $2226-$ 2873 meters above sea level.

The average weather data recorded on the weather station located at Bekoji sub-station near the study area from the years 2017 and 2018 indicate that the mean annual rainfall were 956.6 and $803.5 \mathrm{~mm}$ respectively. The annual mean minimum and maximum air temperature for the consecutive years are $\left(4.7,2 .{ }^{\circ} \mathrm{C}\right)$ and $(18.5,20.3$ $\left.{ }^{0} \mathrm{C}\right)$ respectively.

\subsection{Design and Treatments of the Experiment}

The experiment was set in randomized complete block design by varying levels of phosphorus fertilizer $(0,23$, 46, 69, 92, $115 \mathrm{~kg} \mathrm{ha}^{-1} \mathrm{P}_{2} \mathrm{O}_{5}$, and $\left.46 \mathrm{~kg} \mathrm{ha}^{-1} \mathrm{P}_{2} \mathrm{O}_{5}+40 \mathrm{~kg} \mathrm{ha}^{-1} \mathrm{~K}_{2} \mathrm{O}\right)$ with three replications. The size of each experimental plot was $2.6 \mathrm{~m} * 4 \mathrm{~m}\left(10.4 \mathrm{~m}^{2}\right)$ having ten rows, a distance of $1 \mathrm{~m}$ between plots and $1.5 \mathrm{~m}$ between blocks were left as a path. The recommended planting depth of $6 \mathrm{~cm}$ with spacing of $10 \mathrm{~cm}$ between plants and $40 \mathrm{~cm}$ between rows were used during sowing time. The faba bean variety used for the experiment was Moti. Diammonium phosphate (DAP) used as a source of phosphorus fertilizer which varied depending on treatments were applied as side banding at sowing time and other agronomic practices were kept uniform for all treatments.

\subsection{Soil Sampling and Analysis}

Surface soil, $0-20 \mathrm{~cm}$ depth, were collected from the entire experimental field before planting and after harvesting. The soil was air dried and made fine by using mortar and pestle. The fined soil was passed through $2 \mathrm{~mm}$ sieve and the soil $\mathrm{pH}$, Available $\mathrm{P}$, Total $\mathrm{N}$ and Organic matter were determined at Kulumsa Agricultural soil Laboratory. Soil $\mathrm{pH}\left(\mathrm{H}_{2} \mathrm{O}\right)$ was measured by using a $\mathrm{pH}$ meter in a 1:2.5 soil: water ratio. Soil organic carbon was estimated by the Walkley-Black wet oxidation method. Total nitrogen was determined by the microKjeldahl digestion, distillation and titration method, and available $\mathrm{P}$ was determined using the standard Olsen extraction method. Accordingly, The soil analysis result before planting indicated that the $\mathrm{pH}$ value was 4.83, very strongly acidic (Foth and Ellis, 1997), available phosphorus was $23.02 \mathrm{ppm}$, high (Olsen et al., 1954), total $\mathrm{N}$ was $0.26 \%$, high and Organic matter $6.14 \%$, high (Berhanu, 1980) (Table 1).

Table 1. Mean Value of Soil data $(0-30 \mathrm{~cm})$ before Planting from the experimental sites in Lemu-Bilbilo District

\begin{tabular}{cccc}
\hline $\begin{array}{c}\mathrm{pH} \\
(1: 2.5)\end{array}$ & $\begin{array}{c}\text { Av.P } \\
(\mathrm{ppm})\end{array}$ & $\begin{array}{c}\text { Total N } \\
(\%)\end{array}$ & $\begin{array}{c}\text { OM } \\
(\%)\end{array}$ \\
\hline 4.83 & 23.02 & 0.26 & 6.14 \\
\hline
\end{tabular}

\subsection{Agronomic and yield data collection}

Data of seedling density, tiller per plant, plant height, number of spike per $50 \mathrm{~cm}$, number of pod per plant, number of seed per pod, grain yield, above ground biomass, and 100 seed grain weight were collected in five trials average from each plot. The plant height was measured from the base of the plant to the apical bud of plant and expressed in centimeters. Seedling density and number of spike per $50 \mathrm{~cm}$ were taken by using $50 \mathrm{~cm}$ by $50 \mathrm{~cm}$ quadrant and recorded as a mean value. Pods per plant and seeds per pod counted from five randomly selected plants were converted to mean value and recorded as number of pods per plant and seeds per pod. Grain yield, above ground biomass and thousand seed grain weight were analyzed gravimetrically by using sensitive balance and recorded in units of gram.

\subsection{Statistical Analysis}

The ANOVA procedure of statistical analysis system (SAS Institute, 1996) was used for performing the significance of differences in seedling density, tiller per plant, plant height, number of spike per $50 \mathrm{~cm}$, number of pod per plant, number of seed per pod, grain yield, above ground biomass, and thousand seed grain weight parameters. A post hoc separation of means was done by least significant difference (LSD) test after main effects was found significant at $\mathrm{P} \leq 0.05$.

\subsection{Economic analysis}

As farmers attempt to evaluate the economic benefits of shift in practice, partial budget analysis was done to identify the rewarding treatments. Yield from on-farm experimental plots was adjusted downward by $10 \%$ i.e., 
$5 \%$ for management difference and $5 \%$ for plot size difference, to reflect the difference between the experimental yield and the yield that farmers could expect from the same treatment. Average market grain price of faba bean (ETB $8.00 \mathrm{~kg}^{-1}$ ), farm-gate price of urea fertilizer (ETB $8.00 \mathrm{~kg}^{-1}$ ), and DAP fertilizer (ETB 12.00 $\mathrm{kg}^{-1}$ ) were used for fertilizer application.

\section{RESULTS AND DISCUSSION}

\subsection{Soil Analysis}

The post harvest soil analysis of experimental field showed that the acidity was decreased from 2.01 to $4.5 \%$, residual $\mathrm{P}$ increased from 1.2 to $39.1 \%$, total $\mathrm{N}$ increased from 7.1 to $13.3 \%$ and organic matter increased from 3.0 to $4.9 \%$ by the application of phosphorus fertilizer levels. The treatment received $46 \mathrm{~kg} \mathrm{ha}^{-1} \mathrm{~K}_{2} \mathrm{O}$ fertilizer up on $46 \mathrm{~kg} \mathrm{ha}^{-1} \mathrm{P}_{2} \mathrm{O}_{5}$ decreases $\mathrm{pH}$ by $0.4 \%$, increase residual $\mathrm{P}$, total $\mathrm{N}$ and organic matter by $7.95,3.3$ and $0.8 \%$ respectively (Fig 1 .).

Fig 1. Mean value of soil analysis result $(0-30 \mathrm{~cm})$ after harvest from the experimental sites

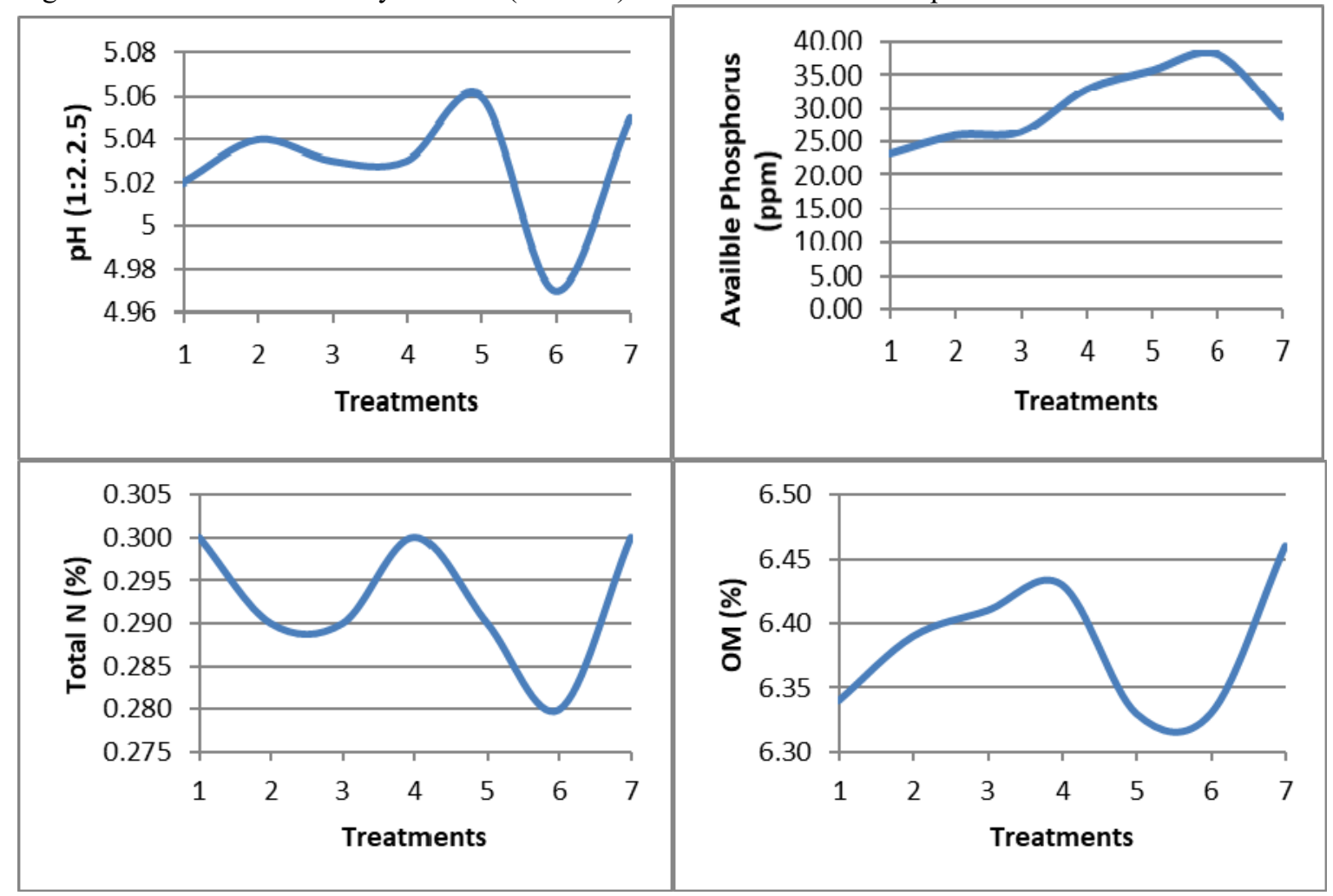

\subsection{Effect of Phosphorus Fertilizer levels on growth of faba bean}

Application of $69 \mathrm{~kg} \mathrm{ha}^{-1}$ resulted in significant difference $(\mathrm{P}<0.05)$ in number of tiller per plant $(1.43)$ for faba bean, which indicated that $\mathrm{P}_{2} \mathrm{O}_{5}$ at the rate of $69 \mathrm{~kg} \mathrm{ha}^{-1}$ might be the optimum rate for improvement of number of tiller per plant. Further increase in phosphorus levels above $69 \mathrm{~kg} \mathrm{ha}^{-1}$ decreases number of tiller per plant linearly (Table 2). Addition of $40 \mathrm{~kg} \mathrm{ha}^{-1} \mathrm{~K}_{2} \mathrm{O}$ over $46 \mathrm{~kg} \mathrm{ha}^{-1} \mathrm{P}_{2} \mathrm{O}_{5}$ increases number of tiller per plant by $12 \%$. This indicates that potassium fertilizer has a significant effect on tillering of faba bean. An increase in application of phosphorus fertilizer levels has no farther difference between treatment on plant height, number of pod per plant and number of spike per $50 \mathrm{~cm}$ at harvest. The maximum number of seed per pod (3.02) was recorded at application of $69 \mathrm{~kg} \mathrm{ha}^{-1}$ phosphorus fertilizer and the lowest at control (2.88). Application of $40 \mathrm{~kg}$ $\mathrm{ha}^{-1} \mathrm{~K}_{2} \mathrm{O}$ decreases plant height, and increases number of pod per plant when compared to the treatment that was received only $46 \mathrm{~kg} \mathrm{ha}^{-1} \mathrm{P}_{2} \mathrm{O}_{5}$. 
Table 3. Main effect of phosphorus fertilizer levels on Tiller per plant, Plant Height, number of pod per plant, number of seed per pod and number of spike per $50 \mathrm{~cm}$ of faba bean

\begin{tabular}{llllll}
\hline Treatments $\left(\mathrm{kg} \mathrm{ha}^{-1} \mathrm{P}_{2} \mathrm{O}_{5}\right)$ & $\mathrm{T} / \mathrm{P}$ & $\mathrm{Ph}(\mathrm{cm})$ & $\mathrm{NP} / \mathrm{P}$ & $\mathrm{NS} / \mathrm{P}$ & $\mathrm{NS} / 50 \mathrm{~cm}$ \\
\hline 0 & $0.92 \mathrm{c}$ & $102.7 \mathrm{~b}$ & $11.66 \mathrm{c}$ & $2.88 \mathrm{~b}$ & $5.35 \mathrm{~b}$ \\
23 & $1.17 \mathrm{~b}$ & $110.8 \mathrm{ab}$ & $13.04 \mathrm{ab}$ & $2.94 \mathrm{ab}$ & $5.67 \mathrm{ab}$ \\
46 & $1.10 \mathrm{bc}$ & $113.6 \mathrm{a}$ & $12.53 \mathrm{bc}$ & $2.99 \mathrm{ab}$ & $5.9 \mathrm{a}$ \\
69 & $1.32 \mathrm{ab}$ & $117.0 \mathrm{a}$ & $13.89 \mathrm{a}$ & $3.02 \mathrm{a}$ & $6.05 \mathrm{a}$ \\
92 & $1.47 \mathrm{a}$ & $119.6 \mathrm{a}$ & $13.98 \mathrm{a}$ & $3.0 \mathrm{ab}$ & $5.96 \mathrm{a}$ \\
115 & $1.19 \mathrm{~b}$ & $118.8 \mathrm{a}$ & $13.33 \mathrm{ab}$ & $2.93 \mathrm{ab}$ & $6.18 \mathrm{a}$ \\
$46+40 \mathrm{~K}_{2} \mathrm{O}$ & $1.46 \mathrm{a}$ & $110.5 \mathrm{ab}$ & $13.3 \mathrm{ab}$ & $2.97 \mathrm{ab}$ & $6.02 \mathrm{a}$ \\
\hline $\mathrm{LSD}(0.05)$ & 0.3 & 9.7 & 1.3 & 0.1 & 0.5 \\
$\mathrm{CV}(\%)$ & 28.1 & 13.0 & 15.0 & 6.6 & 13.9 \\
\hline
\end{tabular}

Note: $T / P=$ tiller per plant; $P h=$ plant height; $N P / P=$ number of pod per plant; $N S / P=$ number of seed per pod; Number of spike per $50 \mathrm{~cm}$

\subsection{Phosphorus Fertilizer levels on yield and yield components of faba bean}

Significantly higher mean grain yield and dry biomass yield (4099.6 and $\left.8127.4 \mathrm{~kg} \mathrm{ha}^{-1}\right)$ obtained with application of $115 \mathrm{~kg} \mathrm{ha}^{-1} \mathrm{P}_{2} \mathrm{O}_{5}$ and the lowest mean grain yield and dry biomass yield (3073.3 and $5713.8 \mathrm{~kg} \mathrm{ha}^{-}$ ${ }^{1}$ ) were obtained at the control. Addition of $\mathrm{K}_{2} \mathrm{O}$ fertilizer didn't made a difference compared to the treatment received only $46 \mathrm{~kg} \mathrm{ha}^{-1} \mathrm{P}_{2} \mathrm{O}_{5}$. The mean harvest index of faba bean was significantly $(\mathrm{P}<0.05)$ affected by different levels of phosphorus fertilizer (Table 3). Significantly higher mean harvest index (54.95\%) was obtained from application of $46 \mathrm{~kg} \mathrm{ha}^{-1} \mathrm{P}_{2} \mathrm{O}_{5}$.

Mean thousand seed weight of faba bean was not significantly $(\mathrm{P}>0.05)$ affected by the main effect of different levels of $P$ fertilizer. This result is in line with that of Nikfarjam and Aminpanah (2015) who suggested that effect of phosphorus application on 100 grain weight was not significant. yield and yield components of faba bean were generally decrease for treatments received $46 \mathrm{~kg} \mathrm{ha}^{-1} \mathrm{P}_{2} \mathrm{O}_{5}+40 \mathrm{~kg} \mathrm{ha}^{-1} \mathrm{~K}_{2} \mathrm{O}$ fertilizers when compared to the treatment that was

received only $46 \mathrm{~kg} \mathrm{ha}^{-1} \mathrm{P}_{2} \mathrm{O}_{5}$ fertilizer.

Table 3. Main effect of phosphorus fertilizer levels on grain yield, Above ground dry biomass, harvest index and thousand seed weight of faba bean

\begin{tabular}{lllll}
\hline Treatments $\left(\mathrm{kg} \mathrm{ha}^{-1} \mathrm{P}_{2} \mathrm{O}_{5}\right)$ & $\mathrm{GY}(\mathrm{Kg} / \mathrm{ha})$ & $\mathrm{BY}(\mathrm{Kg} / \mathrm{ha})$ & $\mathrm{HI}(\%)$ & $\mathrm{TKW}(\mathrm{gm})$ \\
\hline 0 & $3073.3 \mathrm{~d}$ & $5713.8 \mathrm{~d}$ & $54.24 \mathrm{ab}$ & 834.95 \\
23 & $3552.9 \mathrm{c}$ & $6773.3 \mathrm{c}$ & $53.49 \mathrm{ab}$ & 834.35 \\
46 & $3772.0 \mathrm{abc}$ & $6917.5 \mathrm{bc}$ & $54.95 \mathrm{a}$ & 830.73 \\
69 & $3996.8 \mathrm{ab}$ & $7539.6 \mathrm{ab}$ & $53.99 \mathrm{ab}$ & 837.35 \\
92 & $4048.6 \mathrm{a}$ & $7678.5 \mathrm{a}$ & $53.93 \mathrm{ab}$ & 830.49 \\
115 & $4099.6 \mathrm{a}$ & $8127.4 \mathrm{a}$ & $51.33 \mathrm{~b}$ & 836.65 \\
$46+40 \mathrm{~K}_{2} \mathrm{O}$ & $3598.2 \mathrm{bc}$ & $6734.2 \mathrm{c}$ & $54.03 \mathrm{ab}$ & 835.89 \\
\hline LSD $(0.05)$ & 401.8 & 741.7 & 3.3 & $\mathrm{~ns}$ \\
$\mathrm{CV}(\%)$ & 16.3 & 15.9 & 9.3 & 1.5 \\
\hline
\end{tabular}

Note: $G Y=$ grain yield; $A B Y=$ biomass yield; $H I=$ harvest index; $T K W=$ thousand seeds weight

\subsection{Economic Feasibility of Faba Bean Production}

As the result of partial budget analysis, the highest net benefit was obtained from the application of $69 \mathrm{~kg} \mathrm{ha}^{-1}$ $\mathrm{P}_{2} \mathrm{O}_{5}$ was ETB $24862.4 \mathrm{ha}^{-1}$ followed by application of $46 \mathrm{~kg} \mathrm{ha}^{-1} \mathrm{P}_{2} \mathrm{O}_{5}$ (ETB $23664 \mathrm{ha}^{-1}$ (Table 4).

Table 4. Partial budget analysis of phosphorus fertilizer application for faba bean

\begin{tabular}{|c|c|c|c|c|c|}
\hline $\begin{array}{l}\text { Treatments } \quad\left(\mathrm{kg} \quad \mathrm{ha}^{-1}\right. \\
\left.\mathrm{P}_{2} \mathrm{O}_{5}\right)\end{array}$ & $\begin{array}{l}\text { Adjusted grain } \\
\text { yield }\left(\mathrm{kg} \mathrm{ha}^{-1}\right)\end{array}$ & $\begin{array}{l}\text { Gross benefit } \\
\left(\mathrm{kg} \mathrm{ha}^{-1}\right)\end{array}$ & $\begin{array}{l}\text { Total variable } \\
\text { cost }\left(\mathrm{kg} \mathrm{ha}^{-1}\right)\end{array}$ & $\begin{array}{l}\text { Net benefit } \\
\left(\mathrm{kg} \mathrm{ha}^{-1}\right)\end{array}$ & $\begin{array}{l}\text { MRR } \\
(\%)\end{array}$ \\
\hline 0 & 3073.30 & 24586.4 & 5312 & 19274.4D & \\
\hline 23 & 3552.90 & 28423.2 & 5912 & $22511.2 \mathrm{D}$ & \\
\hline 46 & 3772.00 & 30176 & 6512 & 23664 & 192.13 \\
\hline 69 & 3996.80 & 31974.4 & 7112 & 24862.4 & 199.73 \\
\hline 92 & 4048.60 & 32388.8 & 7712 & $24676.8 \mathrm{D}$ & \\
\hline 115 & 4099.60 & 32796.8 & 8312 & $24484.8 \mathrm{D}$ & \\
\hline
\end{tabular}

$D=$ dominated, Urea fertilizer price $=8.00$ Birr kg-1, DAP fertilizer price $=12.00 \mathrm{Birr} \mathrm{kg}^{-1}$, faba bean grain price $=8.00$ Birr $\mathrm{kg}^{-1}, M R R=$ marginal rate of return . 


\section{CONCLUSION}

The post harvest soil analysis of experimental field showed that the acidity was decreased from 2.01 to $4.5 \%$, residual $\mathrm{P}$ increased from 1.2 to $39.1 \%$, total $\mathrm{N}$ increased from 7.1 to $13.3 \%$ and organic matter increased from 3.0 to $4.9 \%$ by the application of phosphorus fertilizer levels. The treatment received $46 \mathrm{~kg} \mathrm{ha}^{-1} \mathrm{~K}_{2} \mathrm{O}$ fertilizer up on $46 \mathrm{~kg} \mathrm{ha}^{-1} \mathrm{P}_{2} \mathrm{O}_{5}$ decreases $\mathrm{pH}$ by $0.4 \%$, increase residual $\mathrm{P}$, total $\mathrm{N}$ and organic matter by $7.95,3.3$ and $0.8 \%$ respectively.

Application of $69 \mathrm{~kg} \mathrm{ha}^{-1}$ resulted in significant difference $(\mathrm{P}<0.05)$ in number of tiller per plant (1.43) for faba bean, which indicated that $\mathrm{P}_{2} \mathrm{O}_{5}$ at the rate of $69 \mathrm{~kg} \mathrm{ha}^{-1}$ might be the optimum rate for improvement of number of tiller per plant. Addition of $40 \mathrm{~kg} \mathrm{ha}^{-1} \mathrm{~K}_{2} \mathrm{O}$ over $46 \mathrm{~kg} \mathrm{ha}^{-1} \mathrm{P}_{2} \mathrm{O}_{5}$ increases number of tiller per plant by $12 \%$. This indicates that potassium fertilizer has a significant effect on tillering of faba bean. The maximum number of seed per pod (3.02) was recorded at application of $69 \mathrm{~kg} \mathrm{ha}^{-1}$ phosphorus fertilizer and the lowest at control (2.88). Application of $40 \mathrm{~kg} \mathrm{ha}^{-1} \mathrm{~K}_{2} \mathrm{O}$ decreases plant height, and increases number of pod per plant when compared to the treatment that was received only $46 \mathrm{~kg} \mathrm{ha}^{-1} \mathrm{P}_{2} \mathrm{O}_{5}$

Application of $115 \mathrm{~kg} \mathrm{ha}^{-1} \mathrm{P}_{2} \mathrm{O}_{5}$ gave significantly higher mean grain yield and dry biomass yield (4099.6 and $8127.4 \mathrm{~kg} \mathrm{ha}^{-1}$ ) obtained with application of $115 \mathrm{~kg} \mathrm{ha}^{-1} \mathrm{P}_{2} \mathrm{O}_{5}$ and the lowest mean grain yield and dry biomass yield ( 3073.3 and $5713.8 \mathrm{~kg} \mathrm{ha}^{-1}$ ) were obtained at the control. Addition of $\mathrm{K}_{2} \mathrm{O}$ fertilizer didn't made a difference compared to the treatment received only $46 \mathrm{~kg} \mathrm{ha}^{-1} \mathrm{P}_{2} \mathrm{O}_{5}$.

Higher net economic return of ETB $24862.4 \mathrm{ha}^{-1}$ and ETB $23664 \mathrm{ha}^{-1}$ were obtained from the application of 69 and $46 \mathrm{~kg} \mathrm{P}_{2} \mathrm{O}_{5} \mathrm{ha}^{-1}$ for faba bean production. Accordingly, treatments with application of $46 \mathrm{~kg} \mathrm{P}_{2} \mathrm{O}_{5} \mathrm{ha}^{-1}$ $\left(192.13 \%{ }^{\mathrm{MRR}}\right)$, and $69 \mathrm{~kg} \mathrm{P}_{2} \mathrm{O}_{5} \mathrm{ha}^{-1}\left(199.73 \%{ }^{\mathrm{MRR}}\right)$ are well above the minimum acceptable rate of return. Generally the result indicated that application of phosphorus $\left(69 \mathrm{~kg} \mathrm{P}_{2} \mathrm{O}_{5} \mathrm{ha}^{-1}\right)$ with grain yield $\left(3996.8 \mathrm{~kg} \mathrm{ha}^{-1}\right)$, is economically feasible treatment for improving productivity of faba bean crop under the conditions of the present study.

\section{REFERENCES}

Bell, R.W., Edwards, D.G. and Asher, C.J., 1990. Growth and nodulation of tropical food legumes in dilute solution culture. Plant and Soil, 122(2), pp.249-258.

Berhanu Debele. 1980. The physical criteria and their rating proposed for land evaluation in the highland region of Ethiopia. Land Use Planning and Regulatory Department, Ministry of Agriculture, Addis Ababa, Ethiopia.

Cordell, D., Drangert, J.O. and White, S. 2009. The story of phosphorus: global food security and food for thought. Global Environmental Change, 19: 292-305.

Ferguson, R.B., Shapiro, C.A., Dobermann, A.R. and Wortmann, C.S. 2006. G87-859 Fertilizer recommendation for soybean (Glycine max L). Historical Materials from University of Nebraska-Lincoln Extension, University of Nebraska, Lincon. 1987pp.

Fitter, A.H. and Hay,R.K.M. 2002. Environmental physiology of plants. London: Academic Press.

Foth, H.D. and Ellis, B.G., 1997. Soil fertility. Soil fertility., (Ed. 2).

Gilbert, N., 2009. The disappearing nutrient: phosphate-based fertilizers have helped spur agricultural gains in the past century, but the world may soon run out of them. Natasha Gilbert investigates the potential phosphate crisis. Nature, 461(7265), pp.716-719.

Giller, K.E. and Wilson, K.J., 2011. Nitrogen fixation in tropical cropping systems (No. 631.84 G481n). Oxon, GB: CAB International, 1991.

Israel, D.W, 1987. Investigation of the role of phosphorus in symbiotic dinitrogen fixation. Plant physiology, 84(3), pp.835-840.

Nikfarjam, S.G. and Aminpanah, H., 2015. Effects of phosphorus fertilization and Pseudomonas fluorescens strain on the growth and yield of faba bean (Vicia faba L.). Idesia, 33(4), pp.15-21.

Olsen, S.R., 1954. Estimation of available phosphorus in soils by extraction with sodium bicarbonate (No. 939). US Dept. of Agriculture.

Rao, I.M. 1996. The role of phosphorus in photosynthesis. pp: 173-194. In: Pessarakli, M. (Eds.), Handbook of Photosynthesis. New York: Marcel Dekker.

Rao, I.M., Friesen, D.K. and Osaki, M. 1999. Plant adaptation to phosphorus-limited tropical soils. pp. 61-96, In: Pessarakli, M. (Eds.), Handbook of Plant and Crop Stress, Madison Avenue, New York: Marcel Dekker.

SAS Institute, 1996. SAS/STAT software: changes and enhancements for release 6.12. Sas Inst.

Sinclair, T.R. and de Wit, C.T., 1975. Photosynthate and nitrogen requirements for seed production by various crops. Science, 189(4202), pp.565-567.

Sara, S., Morad, M. and Reza, C.M., 2013. Effects of seed inoculation by Rhizobium strains on chlorophyll content and protein percentage in common bean cultivars (Phaseolus vulgaris L.). International Journal of Biosciences (IJB), 3(3), pp.1-8.

Vance, C.P., Uhde-Stone, C. and Allan, D.L., 2003. Phosphorus acquisition and use: critical adaptations by 
plants for securing a nonrenewable resource. New phytologist, 157(3), pp.423-447.

Vanlauwe, B., Baijukya, F. and Giller, K.E., 2010. Detailed country-by-country access plan for P and other agrominerals. 